\title{
PERBANDINGAN KEMAMPUAN PEMAHAMAN KONSEP MATEMATIS SISWA MENGGUNAKAN MODEL PEMBELAJARAN TREFFINGER DENGAN MODEL PEMBELAJARAN LANGSUNG PADA SISWA KELAS VIII SMP NOMMENSEN KOTA JAMBI
}

\author{
Elvira Dwi Octariantari ${ }^{1}$, Silvia Fitriani², Aisyah $^{3}$ \\ Program Studi Pendidikan Matematika, FKIP, Universitas Batanghari ${ }^{1,2,3}$ \\ J1. Slamet Riyadi No.1 Broni Jambi \\ e-mail: viradwi1995@gmail.com
}

\begin{abstract}
ABSTRAK
Penelitian ini dilatarbelakangi oleh kemampuan pemahaman konsep matematis siswa yang masih rendah. Hal ini disebabkan oleh guru yang lebih aktif dalam proses pembelajaran, sedangkan siswanya hanya menerima materi, tanya jawab dan mencatat. Untuk membantu siswa agar lebih aktif, guru dapat melakukan perubahan dalam proses pembelajaran salah satunya dengan mencoba atau memilih model pembelajaran yang dapat meningkatkan kemampuan pemahaman konsep matematis siswa yaitu dengan menggunakan model pembelajaran Treffinger. Penelitian ini bertujuan untuk mengetahui perbandingan kemampuan pemahaman konsep matematis menggunakan model pembelajaran Treffinger dengan model pembelajaran Langsung Pada siswa kelas VIII SMP Nommensen Kota Jambi. Penelitian ini merupakan penelitian quasi eksperimen dengan desain The Randomized Postest Only Control yang digunakan terhadap 2 kelas sampel yang diberikan perlakuan berbeda. Sampel dalam penelitian ini adalah seluruh siswa kelas VIII SMP Nommensen Kota Jambi yaitu siswa kelas VIIIa sebagai kelas eksperimen dan siswa kelas VIIIb sebagai kelas kontrol yang diambil secara random. Data penelitian diperoleh dengan memberikan postest kepada kedua kelas sampel. Setelah hasil postest diperoleh, data analisis untuk menguji hipotesis dengan menggunkan uji-t. Dari hasil analisis data yang dilakukan pada dua sampel diperoleh nilai rata-rata dan simpangan baku yang diperoleh kelas eksperimen adalah 77,96 dan 14,12 dan kelas kontrol adalah 64,55 dan 10,99. Dari analisis yang telah dilakukan terhadap postest dapat disimpulkan bahwa kemampuan pemahaman konsep matematis siswa yang menggunakan model pembelajaran Treffinger lebih tinggi daripada kemampuan pemahaman konsep matematis yang menggunakan model pembelajaran Langsung Pada Siswa Kelas VIII SMP Nommensen Kota Jambi.
\end{abstract}

Kata kunci :

Kemampuan Pemahaman Konsep matematis ; model pembelajaran Treffinger; model pembelajaran Langsung.

\begin{abstract}
This research is motivated by the ability of students to understand mathematical concepts that are still low. This is caused by teachers who are more active in the learning process, while students only accept material, questions and answers and take notes. To help students become more active, the teacher can make changes in the learning process, one of them is by trying or choosing a learning model that can improve students' mathematical concept understanding abilities, namely by using the Treffinger learning model. This study aims to determine the comparison of the ability to understand mathematical concepts using the Treffinger learning model with the Direct learning model in eighth grade students of Nommensen Middle School, Jambi City. This research is a quasi-experimental study with The Randomized Postest Only Control design that is used on 2 classes of samples that are given different treatments. The sample in this study were all eighth grade students of Jambi Nommensen Middle School, namely VIIIa class students as the experimental class and VIIIb class students as a control class taken randomly. The research data were obtained by giving posttests to both sample classes. After the posttest results are obtained, the data analysis is to test the hypothesis by using t-test. From the results of data analysis conducted on the two samples obtained the average value and the standard deviation obtained by the experimental class were 77.96 and 14.12 and the control class was 64.55 and 10.99. From the analysis that has been conducted on the posttest it can be concluded that the ability of understanding mathematical concepts of students using Treffinger learning models is higher than
\end{abstract}


the ability of understanding mathematical concepts using Direct learning models in Class VIII Students of SMP Nommensen, Jambi City.

Keywords :

Ability to understand mathematical concepts; Treffinger learning model; Direct learning model.

\section{PENDAHULUAN}

Matematika

merupakan proses interaksi antara guru dan siswa yang melibatkan pengembangan pola berpikir dan mengolah logika pada suatu lingkungan belajar yang sengaja diciptakan oleh guru dengan berbagai metode agar program belajar matematika tumbuh dan berkembang secara optimal dan siswa dapat melakukan kegiatan belajar secara efektif dan efisien. Belajar matematika memerlukan pemahaman terhadap konsep-konsep pada teorema atau rumus.

Pemahaman konsep terhadap setiap materi yang diajarkan guru penting dimiliki setiap siswa karena dapat membantu proses mengingat dan membuat lebih mudah dalam mengerjakan soal-soal matematika yang memerlukan banyak rumus. Menyadari pentingnya pemahaman konsep dalam pembelajaran matematika, maka pembelajaran tersebut perlu direncanakan sedemikian rupa sehingga pada akhir pembelajaran siswa dapat memahami konsep yang dipelajarinya.

Dalam mempelajari matematika, pemahaman konsep matematika sangat penting untuk siswa. Karena konsep matematika yang satu dengan yang lain berkaitan sehingga untuk mempelajarinya harus runtun dan berkesinambungan. Jika siswa telah memahami konsep-konsep matematika maka akan memudahkan siswa dalam mempelajari konsep-konsep metematika berikutnya yang lebih kompleks. Pemahaman konsep matematika sering kita jumpai dalam pengoperasian matematika. Mereka masih keliru dalam menggunakan langkah-langkah dalam menyelesaikan soal pada operasi hitungnya. Mengingat pentingnya pemahaman konsep dalam proses pembelajaran matematika, maka setiap siswa dituntut untuk memiliki kemampuan dalam pemahaman konsep matematika.

Model pembelajaran Treffinger adalah model pembelajaran yang mengembangkan keaktifan siswa untuk mengetahui dan mendalami bahan yang dipelajari. Proses pelaksanaan model pembelajaran treffinger ini dengan sintaks yaitu memahami tantangan, membangkitkan gagasan, dan mempersiapkan tantangan dengan membagi siswa kedalam 5 kelompok kecil. Guru atau calon pendidik akan bertindak sebagai pengawas ataupenilai, bahkan memberikan penguatan jika diperlukan oleh siswa.

\section{METODE PENELITIAN}

Berdasarkan permasalahan yang diteliti, maka jenis penelitian ini termasuk penelitian quasi eksperimen. Dengan cara ini peneliti sengaja membangkitkan timbulnya sesuatu kejadian atau keadaan, kemudian diteliti bagaimana akibatnya. Dengan kata lain quasi eksperimen adalah suatu cara untuk mencari hubungan sebab akibat (hubungan klausal) antara dua faktor yang sengaja ditimbulkan oleh peneliti dengan mengasimilasi atau mengurangi atau menyisihkan faktor-faktor yang bisa mengganggu. (Arikunto, 2002).

Penelitian ini dilakukan pada dua kelas, yaitu kelas eksperimen dan kelas kontrol. Kelas eksperimen merupakan kelas yang menggunakan model pembelajaran Treffinger, dan kelas kontrol merupakan kelas yang menggunakan model pembelajaran langsung.

Populasi dalam penelitian ini adalah seluruh siswa kelas VIII SMP Nommensen Kota Jambi yang terdaftar pada tahun ajaran 2018/2019 yang terdiri dari kelas VIIIa dan VIIIb yang merupakan kelas paralel karena 


\section{$\pi$ (Phi)}

kelas VIII tidak memiliki kelas unggul. Sampel yang digunakan sebanyak dua kelompok sampel yang homogen sebagai kelas eksperimen yang diajarkan dengan model pembelajaran Treffinger dan kelas kontrol yang diajarkan dengan model pembelajaran langsung, maka pengambilan sampel dilakukan dengan teknik Sampling.

Adapun pengambilan sampel pada kelas kontrol dan eksperimen dilakukan secara acak. Berdasarkan permasalahan yang diteliti, maka jenis penelitian ini termasuk penelitian quasi eksperimen. Dengan cara ini peneliti sengaja membangkitkan timbulnya sesuatu kejadian atau keadaan, kemudian diteliti bagaimana akibatnya. Dengan kata lain quasi eksperimen adalah suatu cara untuk mencari hubungan sebab akibat (hubungan klausal) antara dua faktor yang sengaja ditimbulkan oleh peneliti dengan mengasimilasi atau mengurangi atau menyisihkan faktor-faktor yang bisa mengganggu. (Arikunto, 2002).

Penelitian ini dilakukan pada dua kelas, yaitu kelas eksperimen dan kelas kontrol. Kelas eksperimen merupakan kelas yang menggunakan model pembelajaran Treffinger, dan kelas kontrol merupakan kelas yang menggunakan model pembelajaran langsung.

Populasi dalam penelitian ini adalah seluruh siswa kelas VIII SMP Nommensen Kota Jambi yang terdaftar pada tahun ajaran 2018/2019 yang terdiri dari kelas VIIIa dan VIIIb yang merupakan kelas paralel karena kelas VIII tidak memiliki kelas unggul. Sampel yang digunakan sebanyak dua kelompok sampel yang homogen sebagai kelas eksperimen yang diajarkan dengan model pembelajaran Treffinger dan kelas kontrol yang diajarkan dengan model pembelajaran langsung, maka pengambilan sampel dilakukan dengan teknik Sampling. Adapun pengambilan sampel pada kelas kontrol dan eksperimen dilakukan secara acak.
Jurnal Pendidikan Matematika

Volume 3 Nomor 1 Tahun 2019

\section{HASIL DAN PEMBAHASAN}

Uji normalitas kemampuan pemahaman konsep matematis siswa dikelas eksperimen mempunyai nilai x2hitung sebesar 2,93 lebih rendah dari pada x2tabel sebesar 7,81. Dikelas kontrol kemampuan pemahaman konsep matematis siswa mempunyai nilai $\mathrm{x} 2$ hitung sebesar 1,54 lebih rendah dari pada x2 tabel sebesar 7,81. Sehingga dapat disimpulkan bahwa kelas eksperimen dan kelas kontrol berdistribusi normal. uji homogenitas Posstest meghasilkan Fhitung sebesar 1,13 dan Ftabel sebesar 6.31. Oleh karena nilai Ftabel lebih kecil dari pada Ftabel Sehingga dapat disimpulkan bahwa kelas eksperimen dan kelas control mempunyai varians yang homogen. Pengujian hipotesis ini dilakukan dengan uji t, karena data berdistribusi normal dan memiliki varians yang homogen nilai thitung $=2,403$ lebih besar dari ttabel $=$ 1,67 berarti $\mathrm{H} 0$ ditolak atau kemampuan pemahaman konsep matematis siswa yang dibelajarkan dengan model pembelajaran Treffinger lebih tinggi dari pada kemampuan pemahaman konsep matematis siswa yang dibelajarkan dengan model pembelajaran langsung.

Hasil pengujian hipotesis di peroleh bahwa $\mathrm{H} 0$ ditolak dan $\mathrm{H} 1$ diterima. Artinya terdapat perbandingan antara kelas kontrol dan kelas eksperimen. Perbandingan penggunaan model pembelajaran Treffinger dengan model langsung dapat dilihat pada perolehan nilai rata-rata. Nilai rata-rata posttest siswa kelas eksperimen sebesar 77,96, sedangkan rata-rata kelas kontrol sebesar 64,55. Ada beberapa hal yang menyebabkan adanya perbandingan nilai rata-rata antara kelas kontrol dan kelas eksperimen, antara lain proses pembelajaran di kelas.

Tahapan-tahapan pembelajaran dengan model pembelajaran treffinger menjadikan siswa lebih aktif, kreatif dan pembelajaran lebih bermakna. Model pembelajaran treffinger terdiri dari tiga tahapan, yaitu a) 


\section{$\pi$ (Phi)}

understanding challenge, siswa diajak untuk berfikir secara terbuka dalam mengidentifikasi permasalahan, b) generatin gideas, siswa diberi kesempatan untuk mengungkapkan gagasan serta berfikir untuk menyelesaikan permasalahan yang didapat, c) preparing foraction, siswa melakukan eksperimen untuk mendapatkan penjelasan.

Penelitian dengan model pembelajaran treffinger dilakukan dalam beberapa tahapan, tahap pertama, siswa diminta untuk berkelompok, kemudian siswa diminta untuk mengidentifikasi permasalahan. Tahapan ini siswa terlihat tertarik dan termotivasi untuk mempelajari SPLDV, namun model yang dilakukan belum optimal. Tahap kedua, siswa melakukan diskusi dan berfikir secara terbuka untuk menemukan gagasan. Pada tahapan ini, siswa diberi pertanyaan yang mengarahkan siswa pada materi yang disampaikan, siswa membangun pengetahuan sendiri sedangkan guru mengawasi dan memfasilitasi siswa ketika kurang mengerti.

Tahap ketiga, siswa melakukan eksperimen untuk mendapatkan penjelasan mengenai SPLDV dan permasalahan yang diidentifikasi, pada tahapan ini siswa sudah menikmati proses pembelajaran, terlihat dari keaktifan dan antusias siswa dalam melakukan eksperimen, siswa berusaha menemukan konsep dengan teman sekelompok, hampir setiap siswa dalam kelompok menyampaikan ide-ide, serta memberikan tanggapan atas ide-ide yang dikemukakan kelompok lain. Pada tahapan ini, siswa bebas mengungkapkan ide ke semua anggota kelompok dan berusaha meyakinkan kebenaran ide yang disampaikan, sehingga siswa dapat memilih solusi yang menurut mereka lebih tepat dan dapat diterima.

Tahap keempat, siswa diminta untuk menyampaikan kesimpulan dan diberikan permasalahan yang lebih menantang dalam bentuk soal uraian. Penyampaian kesimpulan dan pemberian soal tersebut dilakukan untuk memastikan apakah siswa memahami materi yang telah diterima.

Berdasarkan deskripsi di atas, langkahlangkah model pembelajaran treffinger menuntut siswa untuk menemukan konsep berdasarkan pengalaman langsung, sehingga siswa lebih aktif dan kreatif serta dapat menyelesaikan permasalahan yang lebih kompleks.

Penelitian pada kelas kontrol diajarkan menggunakan model pembelajaran langsung. Pembelajaran diawali dengan pemberian materi secara konvensional, pada tahapan ini siswa tidak aktif karena hanya mendengarkan penjelasan dari guru, tahapan selanjutnya siswa melakukan eksperimen berdasarkan langkah-langkah pada LKS, siswa terlibat langsung dalam proses pembelajaran tetapi siswa hanya terpaku pada LKS dan tidak dapat mengembangkan kreatifitas yang dimilikinya, ketika diberi soal lebih kompleks siswa cenderung masih membutuhkan bimbingan dari guru.

Kelas kontrol dan kelas eksperimen diberikan posttest bentuk soal uraian dengan soal yang sama. Hasil posttest menunjukkan bahwa nilai siswa menggunakan model pembelajaran treffinger lebih tinggi daripada siswa yang menggunakan model pembelajaran langsung pada materi SPLDV. Hasil ini menunjukkan bahwa kemampuan pemahaman konsep matematis siswa yang menggunakan model pembelajaran treffinger lebih tinggi daripada kemampuan pemahaman konsep matematis siswa yang menggunakan model pembelajaran langsung. Hasil penelitian mengungkapkan bahwa penerapan model treffinger dapat meningkatkan kemampuan pemahaman konsep matematis siswa. Paparan di atas dapat memberikan informasi bahwa model pembelajaran treffinger relevan digunakan dalam pelaksanaan pembelajaran matematika. 


\section{SIMPULAN DAN SARAN}

Dari hasil penelitian dan pembahasan yang telah dilakukan dapat disimpulakan bahwa rata-rata kemampuan pemahaman konsep matematis siswa pada materi Sistem persamaan linear dua variabel kelas eksperimen yang dibelajarkan dengan mengunakan model pembelajaran Treffinger memperoleh nilai rata-rata 77,96 dengan simpangan baku 14,12 dan kemampuan pemahaman konsep matematis siswa pada materi Sistem persamaan linear dua variabel kelas kontrol yang dibelajarkan dengan model pembelajaran langsung memperoleh nilai rata-rata 64,55 dengan simpangan baku 10,99 .

Hipotesisnya adalah Kriteria pengujian dari uji statistik dengan mengunakan uji-t, dimana diperoleh thitung $=2,63$ dan ttabel $=$ 1,67. Sesuai dengan kriterian pengujian, jika thitung > ttabel maka $\mathrm{H} 1$ diterima. Ini berarti kemampuan pemahaman konsep matematis siswa yang menggunakan model pembelajaran Treffinger lebih tinggi dibandingkan kemampuan pemahaman konsep matematis siswa yang menggunakan model pembelajaran langsung.

\section{DAFTAR PUSTAKA}

Arikunto, Suharsami. 2002. Manajemen Penelitian. Jakarta: Asdi Mahasatya.

Arikunto, Suharsami. 2014. Prosedur Penelitian Suatu Pendekatan Praktek. Jakarta:Rineka Cipta.

Riduan. 2011. Dasar-Dasar Statistika. Jakarta: Alfabeta.

Rodiah, Imas., Effendi, K. S., dan Hidayat D.2016. "Meningkatkan Kemampuan Pemahaman Konsep Matematis Siswa SMP Melalui Model Treffinger,hlm. 1.

Sugiyono. 2015. Metode Penelitian Pendidikan Pendekatan Kuantitatif, Kualitatif, dan R\&D. Bandung: Alfabeta. 